\title{
超音波による鋳造プロセスの温度モニタリングに関する検討
}

\section{Feasibility Study on Ultrasonic Measurements of Internal Temperature Profiles During Casting Process}

高橋 学・長岡技科大院

Manabu TAKAHASHI, Graduate Student of Nagaoka University of Technology, Nagaoka, Niigata

\author{
井原 郁夫・長岡技科大
}

\begin{abstract}
In this work, an application of the ultrasonic method to internal temperature measurements of materials during casting has been studied. The principle of the method is based on the temperature dependence of the velocity of ultrasonic wave propagating through a material. An inverse analysis coupled with a finite difference calculation is used to determine a one-dimensional temperature distribution. An attempt to monitor both temperatures of a solidifying alloy and a die during casting process has been made. A low melting-point alloy is employed as the melt. Ultrasonic pulse-echo measurements are performed and the changes in the transit times of the reflected echoes through the die and the alloy are continuously acquired, and then the temperature distributions inside the die and the alloy have been estimated during the casting process.
\end{abstract}

Key Words: Ultrasonic measurement, Internal temperature distribution, Casting process, Inverse analysis

\section{1.はじめに}

工業材料の生産・加工プロセスにおいて加工機械や材料の 内部温度およびその分布状態をリアルタイムで測定したい というニーズは数多くある。ダイカストや鋳造工程の場合に は金型内、凝固材料内の温度分布が製品の最終的な品質や精 度に直接影響寸ることからオンラインで材料内の温度分布 を計測するための技術が必要とされている。著者らはこの要 求に応えるべく超音波法の適用について検討している ${ }^{1), 2)}$ この手法の基本原理は音速の温度依存性を利用するもので、 温度センサを測定物の内部に挿人する必要がなく、測定物表 面からの超音波パルスエコーと補助情報（例えば片側の表面 温度）から物体内部の温度を測定することが可能となる。前 報 ${ }^{2)}$ では、この温度同定手法の高速化について検討を行った。 すなわち、超音波伝播時間と差分法解析手法を駆使した新た な定式化を用いることで、差分要素数に依存しない効果的な 温度分布解析が可能となることを検証した。

本報では、鋳造プロセスにおける金型および凝固材料内部 の温度分布計測への上記超音波法の適用について基礎的検 討を行う。低融点合金を凝固材料に用いた鋳造模擬実験を行 い、その凝固過程を超音波パルスエコー法によって計測した。 金型および凝固材料を伝搬する縦波超音波パルスを指標と してそれぞれの内部の温度分布とその変化の同定を試みた。

\section{2. 温度分布解析手法}

片面が一様に加熱されることにより内部に温度勾配をも つ物体を考える。物体内部の温度分布が一次元的であると仮 定すると、物体内をその温度分布方向に伝播する超音波の伝 播時間 $t_{L}$ は次式で与えられる。

$$
t_{L}=2 \int_{0}^{L} \frac{1}{v(T)} d x
$$

ここで、Tは物体内の温度で、一般に加熱面からの距離 $x$ の 関数として表わされる (温度分布)。v(T)は温度 $T$ の関数とし て表される物体の音速である。ある温度範囲に限れば $v(T)$ は 近似的に次の式を用いて表すことができる。

$$
v(T)=\mathrm{A} T^{2}+\mathrm{B} T+\mathrm{C}
$$

ここで、A、B、C は材料固有の值である。台形積分を用い
れば、式(1)は近似的に次式で表すことができる。

$$
t_{L}=h\left(\frac{1}{v_{1}^{n}}+\frac{1}{v_{N}^{n}}\right)+2 h \sum_{i=2}^{N-1} \frac{1}{v_{i}^{n}}
$$

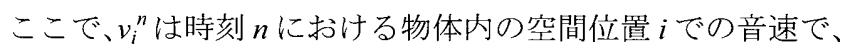
長さ $L$ の物体を刻み $h$ で $N$ 分割したモデルを考えている。今、 ある時刻 $n$ で一様な温度をもつ物体の片面が高温物体との接 触により加熱される場合を考える。物体内部での発熱や対流 がなく、熱伝導率が温度に依存しないとき、僅かな時間経過 後（時刻 $n+1 ） の$ 物体内各点の温度は、両端点 $i=1, N$ を除い て次の差分式を用いて表すことができる ${ }^{3)} 。$

$$
\begin{aligned}
T_{i}^{n+1} & =T_{i}^{n}+r\left(T_{i+1}^{n}+T_{i-1}^{n}-2 T_{i}^{n}\right) \quad(i=2, \cdots, N-1) \\
r & =\frac{\alpha \tau}{h^{2}}
\end{aligned}
$$

ここで、 $\alpha$ は熱搪散率、 $\tau$ は時間刻みである。 $r$ は差分解析の 安定条件を満たすために 0.5 以下とされる。また、高温側の 端点 $i=1$ の温度は次の式により計算される。

$$
\begin{aligned}
& T_{1}^{n+1}=\frac{-\mathrm{B} \pm \sqrt{\mathrm{B}^{2}-4 \mathrm{~A}(\mathrm{C}-\mathrm{D})}}{2 \mathrm{~A}} \\
& \mathrm{D}=\frac{1}{\frac{t_{L}}{h}-\left(\frac{1}{v_{N}^{n+1}}+2 \sum_{i=2}^{N-1} \frac{1}{v_{i}^{n+1}}\right)}
\end{aligned}
$$

ここで $t_{L}$ は時刻 $n+1$ において計測された物体中の超音波伝播 時間である。低温側の端点 $i=N$ の温度が得られれば（何らか の方法で計測するものとする)、式(4)〜(7)より、時刻 $n+1$ で の物体内部の温度分布が得られる。この温度分布の情報と時 刻 $n+2$ の超音波伝播時間を用いることで、時刻 $n+2$ の温度分 布もまた同様にして得られる。このように、超音波伝播時間 の計測を順次続けることで、それらの時刻の温度分布を得る ことができる。この手法を用いて金型内部抢よび凝固材料の 温度分布を同定する。初めに金型内部の温度分布を提案した 超音波法によって求める。次いで、凝固材料内の温度分布を 同定するために、先に求められた金型内壁面の温度を既知情 
報とすることで再度温度分布同定を行なう。

\section{3. 実験}

実験装置の概略を図 1 に示す。厚さ $35 \mathrm{~mm}$ の鋼製金型の側 面に周波数 $5 \mathrm{MHz}$ の超音波探触子が設置されている。この金 型の幅 $20 \mathrm{~mm}$ のキャビティに温度 $150^{\circ} \mathrm{C}$ の低融点合金 $\left(\mathrm{Bi} / \mathrm{Pb} / \mathrm{Cd} / \mathrm{Sn}\right.$ 系、融点 $\left.70^{\circ} \mathrm{C}\right)$ を流し込み、その凝固過程の 超音波パルスエコーを計測した。キャビティ内には凝固材料 の温度变化を測定するために熱電対が設置されている。超音 波探触子と熱電対のそれぞれの計測信号は汎用ソフトウェ アLabVIEW を用いた計測システムにより10 回/秒の速度で 記録される。また、金型側面の温度を赤外線カメラによって 計測し、試験片内部の温度推定の補助情報として用いる。こ のような実験により、凝固時の金型および合金の温度変化を 超音波パルスエコー法によってモニタリングした。

\section{4. 結果と考察}

鋳込み直後からの時間経過にともなう超音波エコー（Bモ ード）の変化を図 2 に示す。金型内面からの反射エコー(A) ならびに合金と金型との界面からの反射エコー(B)が明瞭に 観察される。反射エコー(B)は計測開始後約 45 秒で出現し、 その後、低温の金型との接触によって冷却されることで左方 向に移動している。これは合金の凝固・冷却プロセスに伴う 音速変化を反映したものである。

図 3 に反射エコー（A）および反射エコー（B）の伝播時 間の変化を示す。同図には熱電対で測定した凝固材料内部の 温度変化も示した。反射エコー(A)の伝播時間は熱電対で測 定した温度上昇と同時に変化を開始して抢り、合金を鋳込ん だ直後から金型が急速に加熱されたことが確認できる。また、 反射エコー(B)の伝播時間の変化は反射エコー(A)と比べて大 きく、合金の特性が顕著に変化している様子が分かる。測定 したこれらの伝播時間を用いて金型内部、合金内部の温度分 布を超音波法によって同定した結果を図4 に示す。金型内部 の温度分布解析には赤外線カメラによる金型側面の温度を 既知データとして用いた。金型の温度分布は鋳込み直後、急 激に変化し、次第に温度变化が緩やかになっていることがわ かる。凝固がほぼ完了したと考えられる約 105 秒以降につい ては、超音波法で求めた加熱面の温度を利用して合金内の温 度分布の変化を同定した。ここで、この合金の音速の温度依 存性として次の実験式を用いた。

$$
v(T)=-0.029 T^{2}+0.906 T+2395.6
$$

図 4 の結果についてはさらに検討を要するが、概㱛妥当な 結果が得られたものと考えられる。

\section{謝 辞}

本研究の遂行に際して科学研究費補助金(B19360330)な らびにJFEスチール侏の援助を受けた。記して謝意を表す。

\section{参考文献}

(1)Manabu TAKAHASHI and Ikuo IHARA, Ultrasonic Monitoring of Internal Temperature Distribution in a Heated Material, Japanese Journal of Applied Physics, Vol.47, No.5, pp.3894-3898, 2008.

(2)高橋学、井原郁夫 超音波を用いた温度分布解析における 高速化の検討、第 16 回超音波による非破壊評価シンポジウ 么講演論文集、pp.39-40、2009.

(3)高見穎郎、河村哲也、” 微分方程式の差分解法”, 東京大学 出版会、1994、p.17-26.

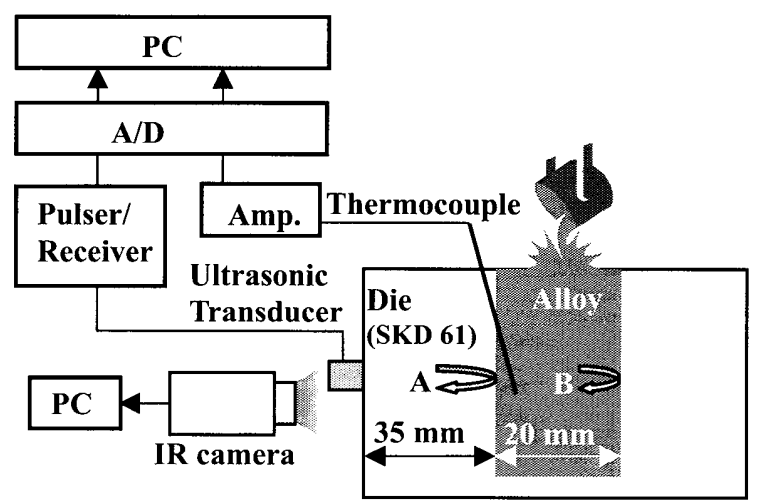

Fig. 1 Schematic of the experimental setup for simultaneously measuring ultrasound pulse-echoes and temperatures.

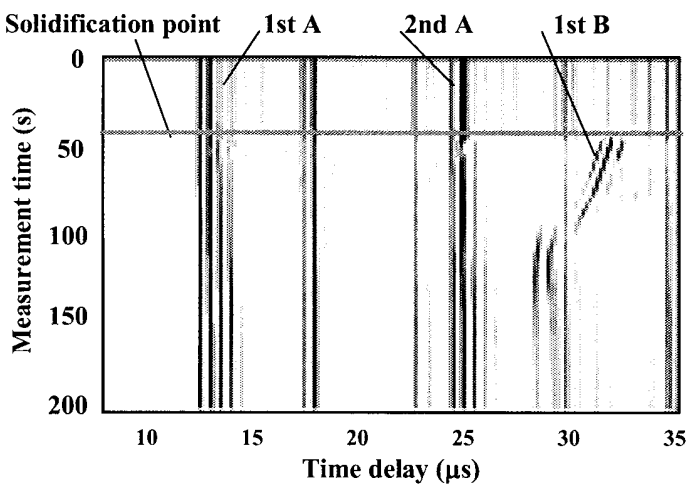

Fig. 2 Variation in B-mode of the reflected echoes with the elapsed time during casting process.

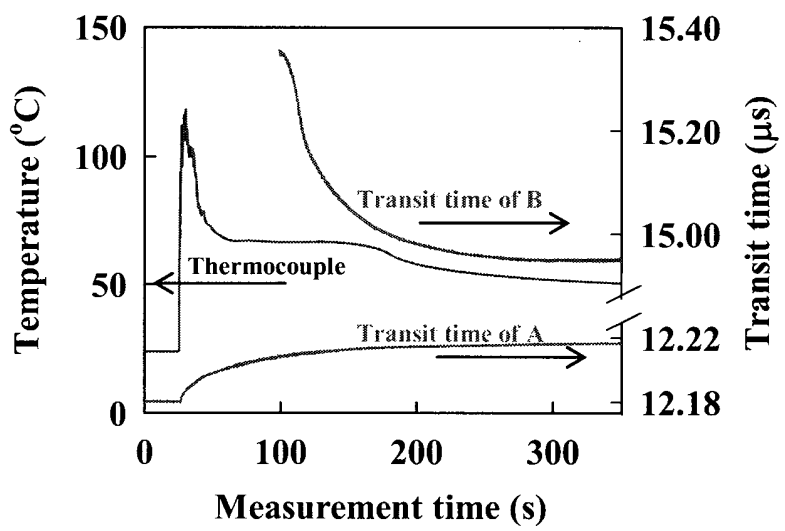

Fig. 3 Variations in ultrasonic transit times propagating through the die and the solidified alloy.

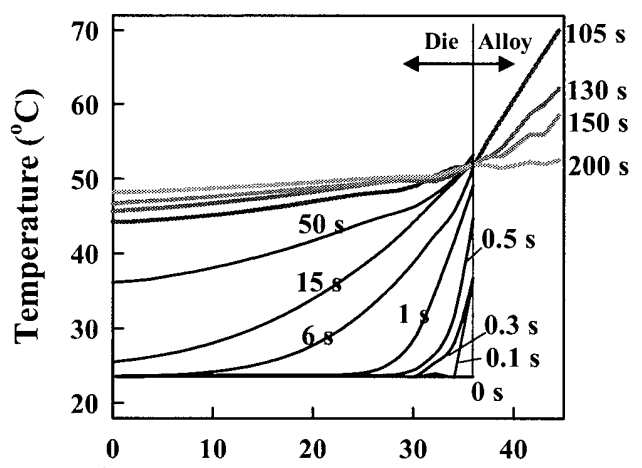

Fig. 4 Variation in temperature profiles for both the die and the alloy during casting process, estimated by the ultrasonic method. 